Prepared for the U.S. Department of Defense, Defense Threat Reduction Agency

under Contract IACRO\#B0946061 and the U.S. Department of Homeland Security

and supported by the Northwest Regional Technology Center for Homeland Security

\title{
Business Continuity Planning Resources for Small- and Medium- Sized Businesses
}

KS Judd

AM Lesperance

May 14,2010
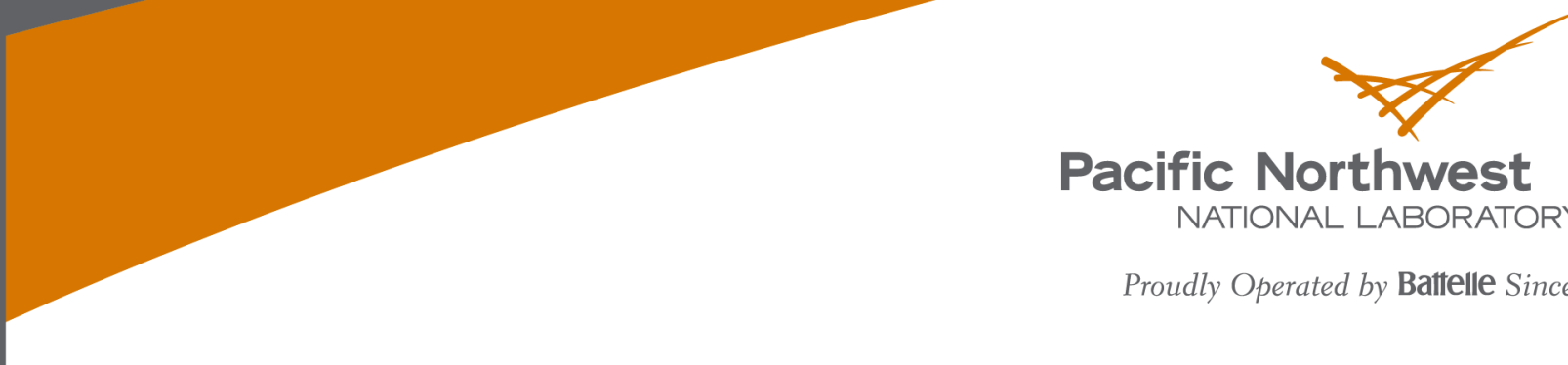

Pacific Northwest

NATIONAL LABORATORY

Proudly Operated by Battelle Since 1965 


\title{
DISCLAIMER
}

This report was prepared as an account of work sponsored by an agency of the United States Government. Neither the United States Government nor any agency thereof, nor Battelle Memorial Institute, nor any of their employees, makes any warranty, express or implied, or assumes any legal liability or responsibility for the accuracy, completeness, or usefulness of any information, apparatus, product, or process disclosed, or represents that its use would not infringe privately owned rights. Reference herein to any specific commercial product, process, or service by trade name, trademark, manufacturer, or otherwise does not necessarily constitute or imply its endorsement, recommendation, or favoring by the United States Government or any agency thereof, or Battelle Memorial Institute. The views and opinions of authors expressed herein do not necessarily state or reflect those of the United States Government or any agency thereof.

\author{
PACIFIC NORTHWEST NATIONAL LABORATORY \\ operated by \\ BATTELLE \\ for the \\ UNITED STATES DEPARTMENT OF ENERGY \\ under Contract DE-AC05-76RL01830
}

Printed in the United States of America
Available to DOE and DOE contractors from the Office of Scientific and Technical Information,
P.O. Box 62, Oak Ridge, TN 37831-0062;
ph: (865) 576-8401
fax: (865) 576-5728
email: reports@adonis.osti.gov

Available to the public from the National Technical Information Service, U.S. Department of Commerce, 5285 Port Royal Rd., Springfield, VA 22161 ph: (800) 553-6847 fax: (703) 605-6900

email: orders@ntis.fedworld.gov

online ordering: http://www.ntis.gov/ordering.htm 


\section{Introduction}

During August 2008, the Pacific Northwest National Laboratory (PNNL) led a series of workshops with businesses, building owners, and critical service providers in the Seattle urban area to identify their priority needs to support restoration and recovery efforts after a wide-area anthrax release. One of the priority issues identified by workshop participants from large commercial businesses was a lack of business continuity planning among the small and mediumsized businesses that they rely on.

Representatives of the large commercial businesses were concerned that many of their suppliers do not have business continuity plans in place, nor do they have the resources and expertise to engage in disaster and recovery planning. Many of these small companies are suppliers to large businesses in the region, and their rapid recovery would be essential to the recovery of the broader regional economy. To support their recovery efforts, the large commercial businesses identified the need to support such smaller critical suppliers with business continuity planning guidance.

In response to this need, PNNL researched existing resources to support business continuity planning for small- to medium-sized businesses and conducted follow-up interviews with workshop participants to determine whether these resources provided adequate business continuity planning guidance. This document summarizes the findings from that effort.

This activity was sponsored by the Defense Threat Reduction Agency (DTRA) in support of the Interagency Biological Restoration Demonstration (IBRD). IBRD is a joint project of the Department of Defense's DTRA and the Department of Homeland Security to develop a blueprint for the recovery and restoration of large urban areas and Department of Defense installations in the event of aerosol release of a biological agent.

\section{Available Resources}

A review of existing resources focused on the availability of relatively simple guidance that either targeted or could be easily used by small- or medium- sized businesses that may not have dedicated business continuity staff or other resources. The primary resources available identified to support these businesses were from the Federal Emergency Management Agency (FEMA), the Institute for Business and Home Safety (IBHS), and the American Red Cross.

Ready Business is an online resource developed by FEMA to help owners and managers of small- and medium-sized businesses prepare their employees, operations and assets in the event 
of an emergency. The website succinctly outlines continuity of operations planning activities and provides a Sample Emergency Plan template. Ready Business has also developed the Ready Business Mentor Guide, which is designed to help business and community leaders host and deliver business preparedness workshops and training sessions. The mentoring sessions aim to present a basic overview of emergency preparedness to business owners and managers, help mentorees begin developing a plan, using the Sample Emergency Plan, and provide suggested activities, planning resources, and informational materials that will help the mentorees take future action.

The Emergency Management Guide for Business and Industry, developed by FEMA in 1993, is a 78-page guide with step-by-step advice on creating and maintaining a comprehensive emergency management program, or assessing and updating an existing company emergency management plan. It provides guidance on how to build emergency management capabilities in key response functional areas such as life safety, property protection and community outreach, in addition to hazard-specific information. It is a more detailed plan that goes beyond continuity of operations planning.

A frequently referenced resource for small and medium sized businesses is Open for Business: A disaster protection and recovery planning toolkit for the small to mid-sized businesses, a 76-page booklet published in 2007 by IBHS. IBHS is a nonprofit initiative of the insurance industry which aims to reduce the social and economic effects of natural disasters and other property losses through research and advocacy of improved construction, maintenance, and preparation practices. The Open for Business website also provides access to a free online training series and a number of forms (e.g. employee contact list, key supplier/vendor information, critical business functions) to support the continuity planning process. Open for Business is designed to streamline the planning process for small businesses and does not require user background in business continuity planning.

The American Red Cross's Preparing your Business for the Unthinkable is a 3-page brochure that outlines a set of considerations to develop a plan and reduce potential damage. The brochure references Open for Business and FEMA's Emergency Management Guide for Business and Industry for more preparing for a disaster.

Finally, a new resource identified launched in Washington State in 2009 is the Disaster Resistant Business (DRB) Toolkit. The DRB Toolkit is customizable, comprehensive software application that guides users through the development of a Business Continuity Program. No prior experience with business continuity planning is needed to use the Toolkit. The Toolkit was developed through a public and private sector collaboration in Washington State. The 
Washington Small Business Development Center is partnering with DRB Toolkit to help make the toolkit widely available to small businesses at no cost.

\section{Interviewee Feedback}

When the representatives of large commercial business were asked whether these or other existing continuity planning resources would address their concerns, most thought these resources would be adequate to support small and medium business with continuity planning. No interviewees identified the need to further develop business continuity guidance.

However, with the exception of one company, the interviewees did not believe that many of their venders were aware of this guidance. It was suggested that the large companies have the responsibility to share this information with their vendors, contractors, and other business partners, and help them develop such plans. Another strategy was to make it a condition for suppliers to have business continuity plans in place One insurance company interviewed noted that they require their insured to develop continuity plans; another is considering such a requirement. 